\title{
Effects of pollution on heterozygosity in the barnacle Balanus amphitrite (Cirripedia: Thoracica)
}

\author{
T. Patarnello ${ }^{1}$, R. Guiñez ${ }^{2}$, B. Battaglia ${ }^{1,3}$ \\ ${ }^{1}$ Department of Biology, University of Padua, via Trieste 75, I-35121 Padova, Italy \\ ${ }^{2}$ Department of Ecology, Pontificia Universidad Católica de Chile, Santiago, Chile \\ ${ }^{3}$ Institute of Marine Biology, CNR Riva Sette Martiri, 1364/A, I-30122 Venezia, Italy
}

\begin{abstract}
The effects of thermal and chemical pollution on gene and genotype frequencies and on multilocus structure were studied in 3 populations of the barnacle Balanus amphitrite Darwin from the lagoon of Venice, Italy. One of these populations (A) was subjected to high chemical pollution; the second (B) was constantly exposed to temperatures about $10^{\circ} \mathrm{C}$ higher than the rest of the lagoon since it was settled in front of an electric power plant outflow; and the third (C) was sampled in an unpolluted area of the lagoon as a control. Juvenile and adult age classes of each of the 3 samples were studied by electrophoretic analysis of the polymorphic loci Mpi, Pgi and Pgm. Significant differences were found between Population $\mathrm{A}$ adults and both $\mathrm{B}$ and $\mathrm{C}$ adults for the majority of the genetic comparisons. $\mathrm{B}$ and $\mathrm{C}$ adult populations did not differ significantly. Statistical comparisons among the 3 juvenile populations showed a high genetic homogeneity. Comparisons between the 2 age classes within each of the 3 populations exhibited significant differences only between adults and juveniles of Population $\mathrm{A}$ at the level of gene and genotype frequencies. Moreover, in Population A a significantly higher survival of the multi-homozygote class was observed. No differences were detected between adults and juveniles of $B$ and $C$ samples. These results suggest the action, in Population $A$, of some selective factor during the post-settlement period. Thermal pollution does not seem to play any important selective role. The hypothesis is advanced that selection is operated by heavy metals
\end{abstract}

\section{INTRODUCTION}

The biological effects of pollution are closely related to increased man-made changes on nature. A number of investigations have focused attention on the ecological, physiological or biochemical consequences of pollution.

A more recent approach is genetic monitoring (Beardmore et al. 1980). It allows comparison of the genetic structures of populations living in polluted and non-polluted areas. Evaluation of spatial-temporal changes of gene and genotype frequencies in relation to the degree of environmental contamination has proved useful in assessing the genetic influence of pollutants (Nevo et al. 1981). Moreover, in some laboratory experiments conducted on genotype survivorship in relation to high concentrations of heavy metals, the fitnesses of the studied genotypes have been demonstrated to be differential, and specific chemical pollutants were characterized as selective factors (Nevo et al. 1983). Such studies have been carried out chiefly on marine organisms since such species are available with biological and genetical characteristics which permit them to be used as 'indicators' (Beardmore et al. 1980).

The required biological properties can be summarized as follows: (1) sessility or very low mobility; (2) widespread distribution and abundance in the area to be monitored; (3) ease of sampling; (4) capacity of filtration and accumulation of pollutants (Majori \& Petronio 1973, Barbaro et al. 1978).

The main genetic characteristic required is a level of polymorphism high enough to clearly indicate changes in gene or genotype frequencies or in multilocus structures among populations from polluted areas (Beardmore et al. 1980).

The present paper reports results comparing the genetic structures of populations of the barnacle Balanus amphitrite Darwin (Cirripedia; Thoracica). Samples were collected in 3 areas of the lagoon of 
Venice, Italy, with different qualities and quantities of pollution. The species concerned has been shown to possess all the required biological (Barbaro et al. 1978) and genetic (Patarnello et al. 1990) properties necessary to the monitoring approach. The analyses were carried out among both adult and juvenile populations.

During recent decades the level of pollution has strongly increased in the lagoon of Venice (Perin \& Gabelli 1983, Alberotanza et al. 1987). This is especially true for the industrial area of Marghera where annual rate of metals discharged in industrial sewage is estimated at 70 tonnes (Perin et al. 1983). Moreover, the presence of an electric power plant (ENEL-CTE) causes, in a part of the industrial area, a condition of thermal pollution.

The aim of the present study was to evaluate the influence of 2 different types of pollution, thermal and chemical, on the genetic structure of Balanus amphitrite.

\section{MATERIALS AND METHODS}

Fig. 1 shows the locations of the sampling stations in the lagoon of Venice: A is situated in the Industrial Channel', where chemical pollution is very high (Perin \& Gabelli 1983, Perin et al. 1983); B lies in front of the outflow of the electrical power plant cooling system where temperatures are constantly raised (by about $10^{\circ} \mathrm{C}$ ) but with low levels of chemical pollution (Donazzolo et al. 1984. Bernardi et al. 1986); C sampled a population at Chioggia, an area in the southern part of the lagoon with low levels of both chemical and thermal pollution (Brunetti et al. 1983, Donazzolo et al. 1984), which was taken as a control population.

Collections from the 3 adult populations were carried out in April and May 1989; 115 individuals were sampled from Population A, 88 from Population B, and 84 from Population C.

Juveniles were collected from 'ad hoc' experimental panels $(19 \times 22 \mathrm{~cm})$. These were immersed in May 1989, $1 \mathrm{~m}$ below mean tide level. Samples were collected $1 \mathrm{wk}$ after settlement. All individuals were transported to the laboratory immediately after collection and frozen at $-40^{\circ} \mathrm{C}$ to be analyzed electrophoretically. The electrophoretic analyses were carried out on cellulose acetate for Mannose-phosphate isomerase (MPI), Phospho-glucose isomerase (PGI) and Phosphoglucomutase (PGM) according to Patarnello et al. (1990)

\section{RESULTS}

In the present study attention was focused on the Mpi, Pgm and Pgi loci since they are the most polymorphic ones in the species considered (Patarnello et al.
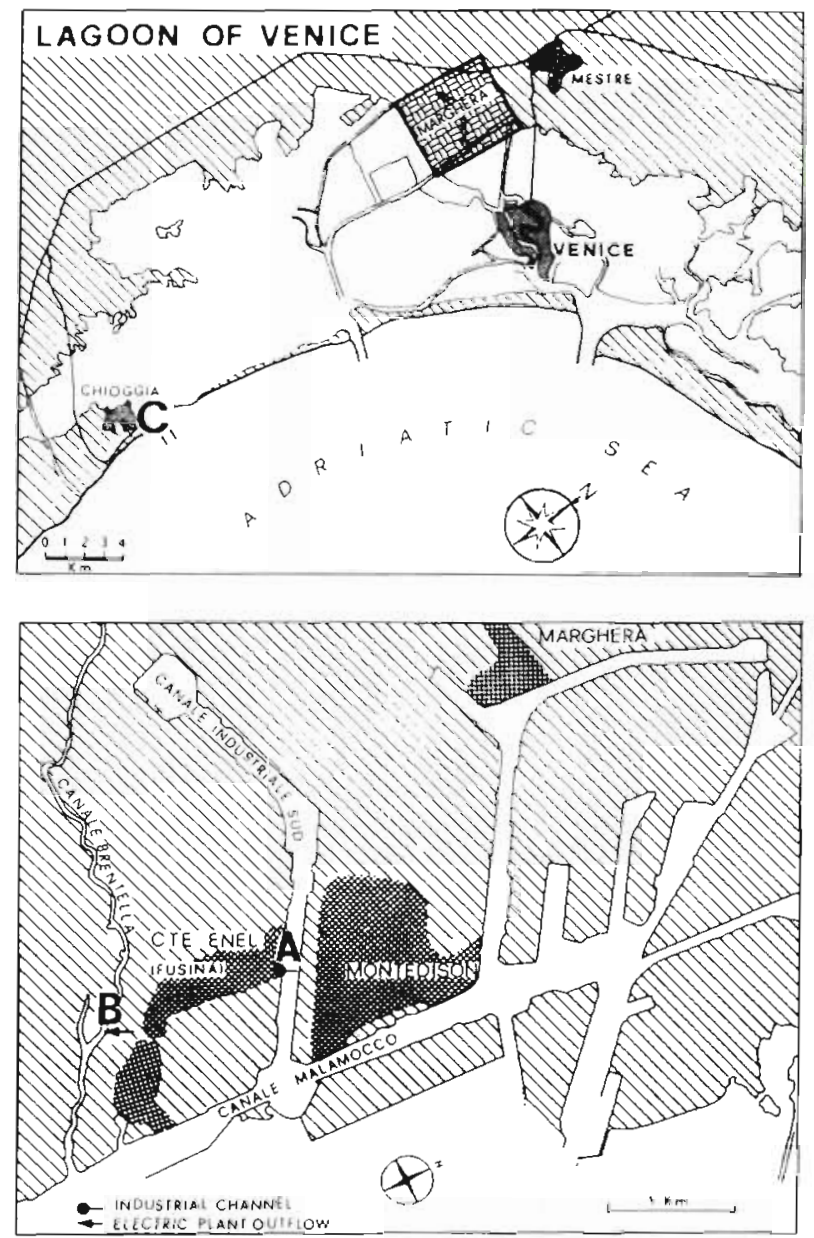

INDUSTRIAL AREA OF MARGHERA

Fig. 1. Sampling areas. A: Industrial Channel; B: electric power plant outflow; C: Chioggia

1990). Results of gene and genotype frequencies for both adult and juvenile populations in the 3 different areas of the lagoon of Venice are reported in Table 1.

Statistical comparison of the genetic structure among adults of the 3 populations shows that Populations $\mathrm{B}$ and $C$ do not differ; on the contrary significant differences are exhibited between both the latter populations and Population A. These differences are clear for both the gene and genotype frequencies, as was shown in a previous study (Patarnello et al. 1990). In particular, Population A, from the Industrial Channel, showed a constant deficiency of heterozygotes that is significant for the Mpi locus, which is not in Hardy-Weinberg equilibrium (Table 1).

Comparing multilocus structures among adults, Population A exhibited a significantly higher percentage of the multi-homozygote class compared with $B$ and $C$ samples (Table 2). This is further evidence of the lower genetic polymorphism of Population A.

On the other hand, the juvenile populations from the 
Table 1. Balanus amphitrite. Gene and genotype frequencies of adults and juveniles in the 3 studied populations. $2 N$ : number of genes scored; $1,2,3,4$ : gene frequency of Alleles $1,2,3,4 ; \mathrm{H}_{o b s}$ : observed heterozygosity; $\mathrm{H}_{\text {exp }}$ : expected heterozygosity; $\mathrm{P}(\mathrm{H}-\mathrm{W})$ : evaluation of the Hardy-Weinberg equilibrium ( $\cdots \mathrm{p}<0.0001$; NS: not significant); $\mathrm{D}=\mathrm{H}_{\text {obs }}-\mathrm{H}_{\exp } / \mathrm{H}_{\exp }$

\begin{tabular}{|c|c|c|c|c|c|c|c|c|c|}
\hline & $2 \mathrm{~N}$ & 1 & 2 & 3 & 4 & $\mathrm{H}_{\text {obs }}$ & $\mathrm{H}_{\exp }$ & $\mathrm{P}(\mathrm{H}-\mathrm{W})$ & $D$ \\
\hline \multicolumn{10}{|c|}{$\begin{array}{l}\text { Population A: Industrial Channel } \\
M p i\end{array}$} \\
\hline Adults & 216 & 0.079 & 0.403 & 0.416 & 0.102 & 0.324 & 0.651 & $\cdots$ & -0.502 \\
\hline Juveniles & 156 & 0.161 & 0.320 & 0.404 & 0.115 & 0.692 & 0.700 & NS & -0.015 \\
\hline \multicolumn{10}{|l|}{ Pgm } \\
\hline Adults & 230 & 0.117 & 0.678 & 0.205 & - & 0.426 & 0.486 & NS & -0.124 \\
\hline Juveniles & 156 & 0.128 & 0.763 & 0.109 & - & 0.423 & 0.392 & NS & -0.078 \\
\hline \multicolumn{10}{|l|}{$P g i$} \\
\hline Adults & 230 & 0.004 & 0.983 & 0.013 & - & 0.035 & 0.035 & NS & -0.009 \\
\hline Juveniles & 156 & 0.032 & 0.949 & 0.019 & - & 0.103 & 0.099 & NS & 0.034 \\
\hline \multicolumn{10}{|c|}{$\begin{array}{l}\text { Population B: Electric power plant outflow } \\
M p i\end{array}$} \\
\hline Adults & 148 & 0.135 & 0.271 & 0.480 & 0.114 & 0.527 & 0.670 & NS & -0.213 \\
\hline Juveniles & 162 & 0.130 & 0.364 & 0.352 & 0.154 & 0.617 & 0.707 & NS & -0.127 \\
\hline \multicolumn{10}{|l|}{$P g m$} \\
\hline Adults & 176 & 0.210 & 0.586 & 0.204 & - & 0.568 & 0.574 & NS & -0.011 \\
\hline Juveniles & 230 & 0.165 & 0.708 & 0.128 & - & 0.460 & 0.456 & NS & 0.009 \\
\hline \multicolumn{10}{|l|}{$P g i$} \\
\hline Adults & 176 & 0.023 & 0.943 & 0.034 & - & 0.090 & 0.109 & NS & -0.168 \\
\hline Juveniles & 234 & 0.035 & 0.923 & 0.042 & - & 0.136 & 0.145 & NS & -0.060 \\
\hline \multicolumn{10}{|c|}{$\begin{array}{l}\text { Population C: Chioggia } \\
\text { Mpi }\end{array}$} \\
\hline Adults & 130 & 0.146 & 0.292 & 0.470 & 0.092 & 0.553 & 0.670 & NS & -0.172 \\
\hline Juveniles & 166 & 0.132 & 0.362 & 0.361 & 0.145 & 0.626 & 0.704 & NS & -0.110 \\
\hline \multicolumn{10}{|l|}{$P g m$} \\
\hline Adults & 164 & 0.202 & 0.621 & 0.177 & - & 0.548 & 0.544 & NS & 0.007 \\
\hline Juveniles & 212 & 0.152 & 0.721 & 0.127 & - & 0.443 & 0.442 & NS & 0.002 \\
\hline \multicolumn{10}{|l|}{$P g i$} \\
\hline Adults & 168 & 0.014 & 0.964 & 0.023 & - & 0.017 & 0.069 & NS & 0.022 \\
\hline Juveniles & 188 & 0.033 & 0.941 & 0.026 & - & 0.117 & 0.112 & NS & 0.040 \\
\hline
\end{tabular}

Table 2. Balanus amphitrite. Statistical comparison of the multilocus structure among the 3 adult populations. Upper right: chi-square values, calculated by contingency tables; lower left: corresponding p-values (1 degree of freedom)

\begin{tabular}{|cccc|}
\hline & $\begin{array}{c}\text { A: } \\
\text { Industrial } \\
\text { Channel }\end{array}$ & $\begin{array}{c}\text { B: } \\
\text { Powerplant } \\
\text { outflow }\end{array}$ & $\begin{array}{c}\text { C: } \\
\text { Chioggia }\end{array}$ \\
\hline $\begin{array}{c}\text { A: Industrial } \\
\text { Channel }\end{array}$ & - & 15.61 & 17.00 \\
$\begin{array}{c}\text { B: Power plant } \\
\text { outflow }\end{array}$ & $\ldots$ & - & 1.06 \\
C: Chioggia & $\ldots$ & NS & - \\
$\ldots$ p $<0.005 ; \ldots$ & $p<0.001$ & & \\
\hline
\end{tabular}

3 areas show high genetic homogeneity. Statistical comparisons carried out both for gene frequencies and observed heterozygosities exhibit no significant differences for all the analysed loci (Table 3). Also not
Table 3. Balanus amphitrite. Gene frequencies and observed heterozygosity comparison among the 3 juvenile populations. Chi-square values $\left(x^{2}\right)$ calculated by contingency tables; df: degrees of freedom; NS: not significant

\begin{tabular}{|lcccc|}
\hline & & Mpi & Pgm & Pgi \\
\hline Gene frequencies & $\chi^{2}$ & 2.790 & 1.555 & 1.954 \\
& $\mathrm{df}$ & 6 & 4 & 4 \\
& $\mathrm{p}$ & $\mathrm{NS}$ & $\mathrm{NS}$ & $\mathrm{NS}$ \\
Heterozygosity & $\chi^{2}$ & 1.171 & 0.270 & 0.538 \\
& $\mathrm{df}$ & 2 & 2 & 2 \\
& $\mathrm{p}$ & $\mathrm{NS}$ & $\mathrm{NS}$ & $\mathrm{NS}$ \\
\hline
\end{tabular}

significant are differences at the level of the multilocus structure among the 3 juvenile samples $\left(\chi^{2}=1.281\right.$, df $=6, p>0.95$; chi-square value obtained by contingency tables).

Comparisons between adults and juveniles within each sampling station show contrasting situations. Populations $\mathrm{B}$ and $\mathrm{C}$ exhibited very high homogeneity for all considered parameters. No significant differ- 
Table 4. Balanus amphitrite. Statistical comparisons of adult and juvenile gene frequencies in the 3 studied populations. Chi-square $\left(\chi^{2}\right)$ values were calculated by contingency tables

\begin{tabular}{|c|c|c|c|c|}
\hline & & $\begin{array}{c}\text { A: Industrial } \\
\text { Channel }\end{array}$ & $\begin{array}{c}\text { B: Power plant } \\
\text { outflow }\end{array}$ & C: Chioggia \\
\hline Mpi & $\begin{array}{l}x^{2} \\
d f \\
p\end{array}$ & $\begin{array}{c}7.821 \\
3 \\
\cdot\end{array}$ & $\begin{array}{c}6.128 \\
3 \\
\text { NS }\end{array}$ & $\begin{array}{c}4.897 \\
3 \\
\text { NS }\end{array}$ \\
\hline$P g m$ & $\begin{array}{l}\chi^{2} \\
d f \\
p\end{array}$ & $\begin{array}{c}6.394 \\
2 \\
.\end{array}$ & $\begin{array}{c}7.216 \\
2 \\
.\end{array}$ & $\begin{array}{c}4.211 \\
2 \\
N S\end{array}$ \\
\hline Pgi & $\begin{array}{l}x^{2} \\
d f \\
p\end{array}$ & $\begin{array}{c}3.590 \\
2 \\
\text { NS }\end{array}$ & $\begin{array}{c}0.700 \\
2 \\
\text { NS }\end{array}$ & $\begin{array}{c}1.744 \\
2 \\
\text { NS }\end{array}$ \\
\hline - $p<$ & 0.05 & & & \\
\hline
\end{tabular}

Table 5. Balanus amphitrite. Statistical comparisons between adults and juveniles at the level of the observed heterozygosity in the 3 studied populations. Chi-square $\left(x^{2}\right)$ values were calculated by contingency tables

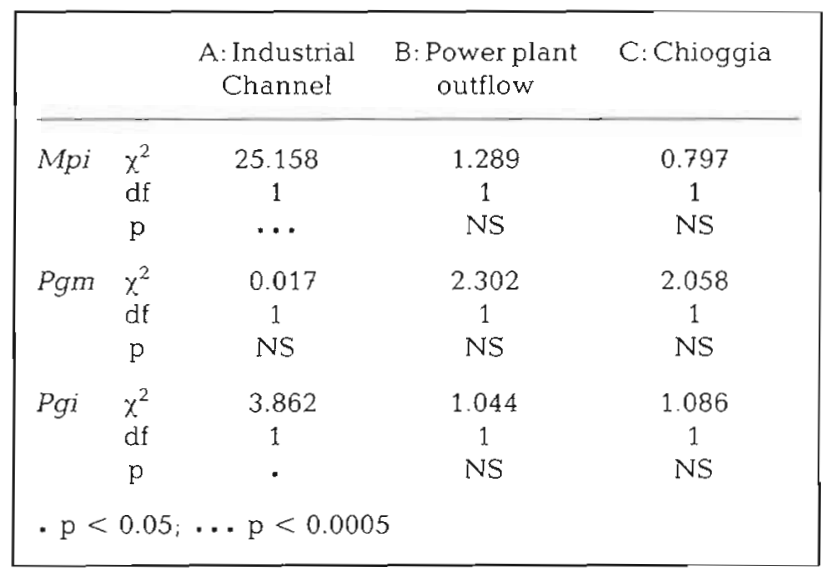

ences between adults and juveniles were found either in gene and genotype frequencies or at the level of the multilocus structure (Tables $4,5 \& 6$ ). The only exception is the Pgm locus of Population B where the gene frequencies were significantly different between the 2 age classes (Tables $1 \& 4$ ).

A different situation was observed in Population A samples where most comparisons show a high genetic difference between adults and juveniles. With regard to gene frequencies, both Mpi and Pgm loci exhibited significant differences (Table 4), whereas the level of observed heterozygosity was significantly lower in the adult population compared with juveniles for $M p i$ and Pgi (Tables 1 \& 5).

Further, when considering the degree of survivorship of the 4 multilocus classes, clear differences among the 3 sampling areas again emerge. Survivorship for each class was calculated as: $\mathrm{S}_{\mathrm{x}}=\mathrm{H}_{\mathrm{x}}$ adults $-\mathrm{H}_{\mathrm{x}}$ juveniles/
Table 6. Balanus amphitrite. Statistical comparisons between adult and juvenile multilocus structure in the 3 studied populations. A: adults; $\mathrm{J}$ : juveniles; $\chi^{2}$ : chi-square values calculated by contingency tables; df: degree of freedom

\begin{tabular}{|c|c|c|c|c|c|c|}
\hline \multirow{3}{*}{$\begin{array}{l}\text { Multilocus } \\
\text { class }\end{array}$} & \multicolumn{6}{|c|}{ Number of individuals } \\
\hline & \multicolumn{2}{|c|}{$\begin{array}{l}\text { A: Industrial } \\
\text { Channel }\end{array}$} & \multicolumn{2}{|c|}{$\begin{array}{l}\text { B: Power plant } \\
\text { outflow }\end{array}$} & \multicolumn{2}{|c|}{ C: Chioggia } \\
\hline & A & $\mathrm{J}$ & A & $\mathrm{J}$ & A & $\mathrm{J}$ \\
\hline 0 & 46 & 14 & 16 & 14 & 15 & 14 \\
\hline 1 & 42 & 35 & 28 & 36 & 34 & 29 \\
\hline 2 & 14 & 27 & 26 & 27 & 25 & 26 \\
\hline 3 & 2 & 2 & 2 & 4 & 4 & 4 \\
\hline$x^{2}$ & \multicolumn{2}{|c|}{18.49} & \multicolumn{2}{|c|}{1.29} & \multicolumn{2}{|c|}{0.29} \\
\hline $\mathrm{p}$ & \multicolumn{2}{|c|}{$<0.0005$} & \multicolumn{2}{|c|}{ NS } & \multicolumn{2}{|c|}{ NS } \\
\hline $\mathrm{df}$ & \multicolumn{2}{|c|}{3} & \multicolumn{2}{|c|}{3} & \multicolumn{2}{|c|}{3} \\
\hline
\end{tabular}

$\mathrm{H}_{X}$ juveniles, where $\mathrm{H}_{x}$ is the percentage value of the $X$ multilocus class and $S_{x}$ is the survivorship value. Following this procedure revealed a remarkable ability to survive of the multi-homozygous class in Population A (Fig. 2). This survivorship is considerably higher than both Populations B and C, which show similar behaviours to each other (Fig. 2).

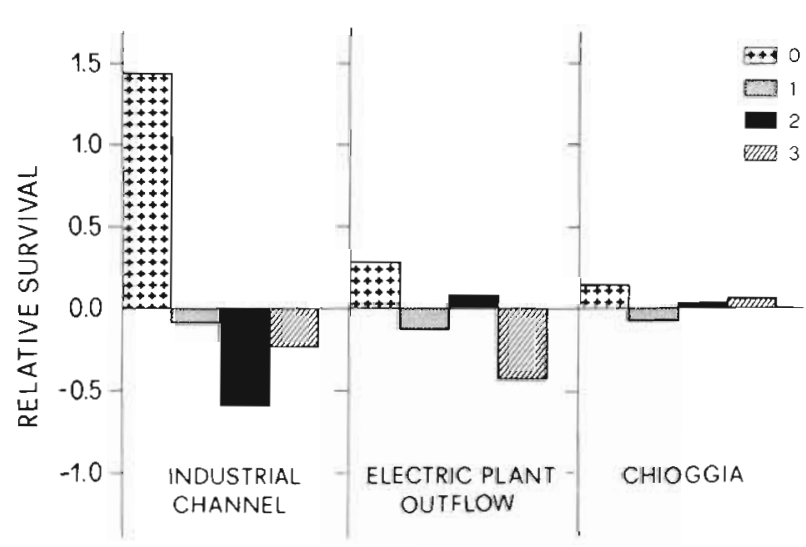

Fig. 2. Balanus amphitrite. Relative survival of the 4 multilocus classes. 0: class with no heterozygous loci; 1 . class with 1 heterozygous locus; 2 : class with 2 heterozygous loci; 3 : class with 3 heterozygous loci; 4 : class with 4 heterozygous loci. For calculation of the survival value ( $\mathrm{Sx}$ ) of each multilocus class see text

\section{DISCUSSION}

The comparisons of genetic structure among the 3 adult populations clearly indicate differences between the samples from the Industrial Channel and those from the electric power plant outflow and Chioggia.

Since the Chioggia population represents a good 'control', as shown by the Hardy-Weinberg equilibrium 
and the lack of significant differences between juveniles and adults, and since the power plant outflow population does not show any genetic difference compared with Chioggia, these 2 samples may be considered unaffected by any genetic perturbation.

On the other hand, since most genetic comparisons show significant differences between the Industrial Channel population and the 2 others, it is reasonable to postulate the action of a selective factor (Patarnello et al. 1990). The one most likely responsible for this selection is chemical pollution.

The high concentrations of heavy metals in the Industrial Channel of the Marghera area are extensively described in the literature (Perin \& Gabelli 1983, Perin et al. 1983, Alberotanza et al. 1987). Our observations on sediments from the 3 stations confirm the above findings. Measurements of the heavy metals $\mathrm{Cu}_{t}$ $\mathrm{Cd}, \mathrm{Mn}, \mathrm{Ni}, \mathrm{Cr}, \mathrm{Co}, \mathrm{Fe}, \mathrm{Zn}, \mathrm{Pb}$ and $\mathrm{Hg}$ have shown the Industrial Channel sediment to contain concentrations at least 4 times higher than those found in sediments from the power plant outflow and Chioggia. The 2 latter samples exhibit values that can be considered within the normal range (Patarnello \& Campesan unpubl.).

The genetic effects of chemical pollution were demonstrated in early studies conducted on other marine invertebrates from the lagoon of Venice (Battaglia et al. 1980) and in a population of Balanus amphitrite from Haifa Bay (Israel) (Nevo et al. 1978). In both cases a significant reduction of genetic polymorphism was detected, in agreement with the present results.

In contrast studies conducted on the marine gastropod Littorina littorea and the bivalve Mytilus edulis failed to show any genetic effect of chemical (oil) pollution (Fevolden \& Garner 1986, 1987). For L. littorea this could have been due to the very low genetic polymorphism found in populations of that gastropod that makes the species unsuitable for such monitoring, although other gastropods proved sensitive to various chemical pollutants (Lavie \& Nevo 1987, Nevo et al. 1987), including oil (Nevo \& Lavie 1989).

Among chemical pollutants, the effects of heavy metals were the object of most investigations. Their selective action has been demonstrated in several laboratory experiments where genotype fitnesses were found to be differentially affected by high concentrations of these pollutants (Lavie \& Nevo 1982, 1986, 1987, Nevo et al. 1981, 1983, 1984, 1985, 1987).

The present data do not allow the attribution of any selective role to thermal pollution since the power plant outflow population exhibited no significant genetic difference compared to the 'control' population. This seems to contrast with results described by Nevo et al. (1977) in previous studies on Balanus amphitrite. It could be explained by a genetic adaptation of the Venetian populations of this species to the wide fluctuations of temperature that characterize the Venetian lagoon during the year in comparison with the more stable environment provided by the open sea of Haifa Bay. Research to test this hypothesis is being planned.

With regard to the genetic selection in relation to age class, the results on juveniles of the 3 populations indicate that selection occurs during the post-settlement period, leading to differential genotype survival where multi-homozygote individuals possess higher fitness. The genetic homogeneity of the juvenile samples from the 3 areas is showed by the statistical comparisons carried out at the levels of gene and genotype frequencies and multilocus structure. It can be accounted for by the existence in the lagoon of a large pool of larvae coming from different areas of the lagoon, including the 3 stations considered in the present study which are separated by about $20 \mathrm{~km}$.

It is believed that barnacles have a larval planktonic stage of about $1 \mathrm{wk}$ (Whethey 1986), a period long enough for the larvae to cover 20 or $30 \mathrm{~km}$ according to the hydrodynamics of the lagoon. Therefore during the reproductive period, from April to August (Barbaro \& Francescon 1976), the formation of a larval pool permits the mixing of the genetic characteristics of the different adult populations. If the latter are not genetically different, no differences between juveniles and adults would be expected in the various areas. On the other hand, if some local population is subjected to selective pressure that makes it genetically different from the neighbouring ones, 2 scenarios are possible:

(1) Pre-settlement selection: very low genetic differentiation between juveniles and adults of the selected population, high differences between juveniles of this population compared with all other juveniles;

(2) Post-settlement selection: very low genetic similarity between adults and juveniles of the selected population, no differences among the juveniles of this selected population and other juveniles.

The present data clearly support the hypothesis of post-settlement selection.

The validity of this hypothesis is supported by the consideration that Balanus amphitrite is a suspensionfeeder and has the capacity to accumulate chemical pollutants (heavy metals) during growth up to $10^{2}$ or $10^{3}$ times ambient levels, as shown by Barbaro et al. (1978). It is likely that, when heavy metal concentrations reach certain levels in the tissue, only some genotypes are able to survive, as shown by laboratory experiments on other marine invertebrates (Hvilsom 1983).

With regard to the multilocus structure, our finding of a higher fitness of multi-homozygote individuals may seem unexpected since in some studies conducted on 
marine molluscs a significant correlation has been detected between multi-heterozygosity and parameters of fitness such as growth (Koehn \& Gaffney 1984 , Diehl \& Koehn 1985, Koehn et al. 1988). However, although the multi-heterozygotus individuals showed a clearly reduced energetic demand for maintenance and a higher energetic investment in production (with consequent higher fitness) (Hawkins et al. 1989), the mechanism that confers such an advantage to multiheterozygote genotypes remains to be elucidated; several hypotheses have been advanced (for reviews see Zouros \& Foltz 1987, Zouros \& Mallet 1989)

The selection due to heavy metals is very likely to act directly on protein modifying its enzymatic characteristics (Nevo et al. 1983). Considering that the loci analysed in the present work are involved in the glycolytic pathway it seems reasonable to assume that a differential enzymatic efficiency influences fitness. It has been long known that certain heavy metals are able to inhibit glycolysis (Webb 1966). Moreover, in most cases where heavy metals have been demonstrated to act as selective factors, the loci affected by such a selection were shown to be those considered in the present work (Lavie \& Nevo 1982, 1987, Nevo \& Lavie 1989, Nevo et al. 1981, 1983, 1984). These loci (Mpi, Pgi, Pgm), due to their metabolic role, can be considered very sensitive to chemical pollution.

The higher fitness of some homozygote genotypes observed in Balanus amphitrite could be the result of a minor modification in the enzymatic properties of the protein coded by the adaptively superior genotype.

It is therefore desirable to extend the investigations at the level of in vivo and in vitro laboratory experiments in order to evaluate the mechanism by which heavy metals are able to affect genotype fitness. Attention should be focused on loci functionally interrelated and involved in important metabolic pathways where it may be expected that differential enzymatic efficiency results in differential fitness (Koehn et al. 1988, Patarnello et al. 1989).

Acknowledgements. This research was supported by ENEL (Ente Nazionale per l'Energia Elettica). We thank Dr A. Barbaro for his help in the classification of the samples.

\section{LITERATURE CITED}

Alberotanza, L., Donazzolo, R., Orio, A. A., Pavoni, B., Zandonella, A. (1987). La dinamica dell'inquinamento nella laguna e nel golfo di Venezia. Inquinamento 3: 82-89

Barbaro, A., Francescon, A. (1976). I periodi di insediamento dei principali organismi del 'fouling' nelle acque di Venezia. Archo Oceanogr. Limnol. 18: 195-216

Barbaro, A., Francescon, A., Polo, B., Bilio, M. (1978). Balanus amphitrite (Cirripedia: Thoracica) - a potential indicator of fluoride, copper, lead, chromium, and mercury in north Adriatic lagoons. Mar. Biol. 46: 247-257

Battaglia, B., Bisol, P. M., Rodinò, E. (1980). Experimental studies on the genetic effects of the marine pollution. Helgoländer Meeresunters. 33: 587-595

Beardmore, J. A., Barker, C. J., Battaglia, B., Berry, R. J. Longwell, A. C., Payne, J. F., Rosenfield, A. (1980). The use of the genetic approaches to monitoring biological effects of pollution. Rapp. P.-v. Réun. Cons. int. Explor. Mer 179: 299-305

Bernardi, S., Cecchi, R., Costa, F., Ghermandi, G., Vazzoler, S. (1986). Trasferimenti di acqua dolce ed inquinanti nella laguna di Venezia. Inquinamento 1/2: 1-20

Brunetti, R., Marin, M. Beghi, L., Bressan, M. (1983). Study of pollution in the Venetian lagoon's lower basin during the period 1974-1981. Riv. Idrobiol. 22: 27-58

Diehl, W.. Koehn, R. K. (1985). Multiple-locus heterozygosity, mortality and growth in a cohort of Mytilus edulis. Mar. Biol. 88: 256-271

Donazzolo, R., Orio, A. A., Pavoni, B., Perin, G. (1984). Heavy metals in sediments of the Venice Lagoon. Oceanologica Acta 7: 25-31

Fevolden, S. E., Gamer, S. P. (1986). Population genetics of Mytilus edulis (L.) from Oslofjorden, Norway, in oil-polluted and non oil-polluted water. Sarsia 71: 247-257

Fevolden, S. E., Garner, S. P. (1987). Environmentál stress and allozyme variation in Littorina littorea (Prosobranchia). Mar. Ecol. Prog. Ser. 39: 129-136

Hawkins, A. S. J., Bayne, B. L., Day, A. J., Rusin, J., Worrall, C. M. (1989). Genotype-dependent interrelation between energy metabolism, protein metabolism and fitness. In: Ryland, J. S., Tyler, P. A. (eds.) Reproduction, genetics and distribution of marine organisms. 23rd Eur. Mar. Biol. Symp. Olsen \& Olsen, Fredensborg, p. 283-292

Hvilsom, M. M. (1983). Copper-induced differential mortality in the mussel Mytilus edulis. Mar. Biol. 76: 291-295

Koehn, R. K., Diehl, W. J., Scott, T M. (1988). The differential contribution by individual enzymes of glycolysis and protein catabolism to the relationship between heterozygosity and growth rate in the coot clam Mulinia lateralis. Genetics 118: 121-130

Koehn, R. K., Gaffney, P. M. (1984). Genetic heterozygosity and growth rate in Mytilus edulis. Mar. Biol. 82: 1-7

Lavie, B., Nevo, E. (1982). Heavy metal selection of phosphoglucose isomerase allozymes in marine gastropods. Mar. Biol. $71: 17-22$

Lavie, B., Nevo, E. (1986). The interactive effects of cadmium and mercury pollution on allozymes polymorphism in marine gastropods Cerithium scabridum. Mar. Pollut. Bull. $17 \cdot 21-23$

Lavie, B., Nevo, E. (1987). Differential fitness of allelic isozymes in the marine gastropods Littorina punctata and Littorina neritoides, exposed to environmental stress of the combined effects of cadmium and mercury pollution. Environ. Mgmt 11:345-349

Majori, L., Petronio, L. (1973). Marine pollution by metals and their accumulation by biological indicators (accumulation factors). Revue int. Océanogr méd. 31-32: 55-90

Nevo, E., Ben-Shlomo, R., Lavie, B. (1984). Mercury selection of allozymes in marine organisms: prediction and verification in nature. Proc natn. Acad. Sci. U.S.A. 81. 1258-1259

Nevo, E. Lavie, B. (1989). Differential viability of allelic isozymes in the marine gastropod Cerithium scabridum exposed to the environmental stress of nonionic detergent and crude oil-surfactant mixture. Genetica 78: 205-213

Nevo, E., Lavie, B., Ben-Shlomo, R. (1983). Selection of allelic isozyme polymorphism in marine organisms: pattern, 
theory, and application. In: Rattazzi, M. C., Scandalios, J. G., Whitt, G. S. (eds.) Isozymes: current topics in biological and medical research, Vol. 10. Liss, New York, p. 69-92

Nevo, E., Lavie, B., Noy, R. (1987). Mercury selection of allozymes in marine gastropods: prediction and verification in nature revisited. Environ. Monitg Assessmt 9: 233-238

Nevo, E., Noy, R., Lavie, B., Muchtar, S. (1985). Level of genetic diversity and resistance to pollution in marine organisms. FAO, Rome, FIRI/R352 (Suppl.) p. 175-181

Nevo, E., Perl, T., Beiles, A., Wool, D. (1981). Mercury selection of allozyme genotypes in shrimps. Experientia 37 $1152-1154$

Nevo, E., Shimony, T., Libni, M. (1977). Thermal pollution of allozyme polymorphis in barnacles. Nature, Lond. 267 $699-700$

Nevo, E., Shimony, T., Libni, M. (1978). Pollution selection of allozyme polymorphism in barnacles. Experientia 34: $1562-1564$

Patarmello, T., Bisol, P. M., Battaglia, B. (1989). Studies on differential fitness of PGI genotypes with regard to temperature in Gammarus insensibilis (Crustacea: Amphipoda) Mar. Biol. 102: 355-359

Patarnello, T., Guinez Diaz, R., Bressa, G., Battaglia, B. (1990) Effetti genetici dell'inquinamento in popolazioni lagunari

This article was submitted to the editor di Balanus amphitrite Darwin (Cirripedia: Thoracica) Rend. Fis. Acc. Lincei s. 9, v. 1: 193-202

Perin, G., Gabelli, A. (1983). Inquinamento chimico della laguna di Venezia. Contaminanti di origine urbana ed industriale nelle acque. Acqua \& Aria 6: 615-621

Perin, G., Orio, A. A., Pavoni, B., Donazzolo, R., Pastre, B., Carniel, A., Gabelli, A., Pasquetto, A. (1983). Nutrienti e metalli pesanti nei sedimenti. Acqua \& Aria 6: 623-632

Webb, J. L. (1966). Enzyme and metabolic inhibitors, Vol. 2. Academic Press, New York

Whethey, D. S. (1986). Local and regional variation in settlement and survival in the intertidal barnacle Semibalanus balanoides: patterns and consequences. In: Moore, P. G. Seed, R. (eds.) The ecology of rocky coasts. Hodder and Stoughton, Sevenoaks, p. 194-202

Zouros, E., Foltz, D. W. (1987). The use of allelic isozyme variation for the study of heterosis. In: Rattazzi, M. C., Scandalios, J. G., Whitt, G. S. (eds.) Isozymes: current topics in biological and medical research, Vol. 13. Liss, New York, p. 1-59

Zouros, E., Mallet, A. L. (1989). Genetic explanation of the growth/heterozygosity correlation in marine mollusks. In: Ryland, J. S., Tyler, P. A. (eds.) Reproduction, genetics and distributions of marine organisms. 23rd Europ. Mar. Biol. Symp. Olsen \& Olsen, Fredensborg, p. 317-323

Manuscript first received: April 11, 1990

Revised version accepted: September 10, 1990 